\title{
Endoscopic Ultrasonography (EUS) Compared with Magnetic Resonance Cholangiopancreatography (MRCP) in Diagnosing Patients with Malignancy Causing Obstructive Jaundice
}

\author{
Kaka Renaldi*, Rudy Kurniawan**, Dadang Makmun* \\ *Division of Gastroenterology, Department of Internal Medicine, Faculty of Medicine, \\ Universitas Indonesia/Dr. Cipto Mangunkusumo National General Hospital, Jakarta \\ ${ }^{* *}$ Faculty of Medicine, Universitas Indonesia/Dr. Cipto Mangunkusumo National General Hospital, \\ Jakarta
}

Corresponding author:

Kaka Renaldi. Division of Gastroenterology, Dr. Cipto Mangunkusumo General National Hospital. Jl Diponegoro No.71 Jakarta Indonesia.Phone: +62-21-3153957; Facsimile: +62-21-3142454.E-mail: kakarenaldi@gmail.com

\begin{abstract}
Background: The common etiologies of obstructive jaundice were biliary stone and biliary neoplasms. The gold standard to diagnose malignancy causing obstructive jaundice is endoscopic retrograde cholangiopancreatography (ERCP) with sensitivity and specificity of $>95 \%$ and $100 \%$. However, ERCP is an invasive procedure associated with several complications such as bleeding, pancreatitis, and perforation. Other modalities include endoscopic ultrasonography (EUS) and magnetic resonance cholangiopancreatography (MRCP). Thus, we aim to evaluate the sensitivity and specificity of EUS with MRCP in patients with malignancy causing obstructive jaundice.

Method: This was a cross-sectional study that calculates the sensitivity and specificity of EUS and MRCP in diagnosing malignancy causing obstructive jaundice compared with the gold standard, histopathology examination from ERCP. The study was conducted in the Medical Record Unit, Gastroenterology Division, Dr. Cipto Mangunkusumo National General Hospital, on January - March 2019 by using a consecutive sampling method. The date of diagnosis was collected from the medical record within five years. Subjects were selected based on inclusion criteria which include patients aged $\geq 18$ years old who were diagnosed with malignancy causing obstructive jaundice by ERCP, and had underwent EUS or MCRP with a maximum interval of 3 months to ERCP. The exclusion criteria include patients with previous evidence of biliary tract malignancy or concurrent parenchymal jaundice. Statistical analysis was performed using IBM SPSS Statistics 20.

Results: There were 54 subjects with a mean age of $56.48 \pm 11.37$ years. Subjects consisted of 29 (53.7\%) males and 25 (46.3\%) females. The median period between EUS to ERCP was 0-33 days, while MRCP to ERCP was 1-53 days. The sensitivity, specificity, positive predictive value, and negative predictive value to diagnose obstructive jaundice due to malignancy were $96 \%, 60 \%, 96 \%, 60 \%$ in EUS, and $90 \%, 40 \%, 94 \%, 29 \%$ in MRCP, respectively.
\end{abstract}

Conclusion: EUS was more superior to MRCP in the diagnosis of malignancy causing obstructive jaundice.

Keywords: endoscopic ultrasonography (EUS), malignancy, magnetic resonance cholangiopancreatography (MRCP), obstructive jaundice 


\section{ABSTRAK}

Latar belakang: Etiologi paling sering dari ikterus obstruktif adalah batu empedu dan neoplasma bilier. Pemeriksaan baku emas untuk mendiagnosis keganasan yang menyebabkan ikterus obstruktifadalah endoscopic retrograde cholangiopancreatography (ERCP), dengan sensitivitas dan spesifisitas $>95 \%$ dan 100\%. Namun, ERCP merupakan prosedur invasif yang sering dikaitkan dengan beberapa komplikasi seperti perdarahan, pankreatitis, dan perforasi. Oleh karena itu, studi ini bertujuan untuk mengevaluasi sensitivitas dan spesifisitas endoscopic ultrasonography (EUS) dibandingkan dengan magnetic resonance cholangiopancreatography (MRCP) pada pasien dengan keganasan yang menyebabkan ikterus obstruktif.

Metode: Penelitian ini merupakan studi potong lintang yang menghitung sensitivitas dan spesifisitas modalitas diagnosis EUS dan MRCP pada pasien dengan keganasan yang menyebabkan ikterus obstruktif dibandingkan dengan modalitas diagnosis standar, yaitu pemeriksaan histopatologi dari ERCP. Penelitian dilakukan di Unit Rekam Medis, Bagian Gastroenterologi RSUD Dr. Cipto Mangunkusumo pada bulan Januari - Maret 2019 dengan metode pengambilan sampel konsekutif. Data diagnosis dikumpulkan dari rekam medis periode 20142019. Subyek dipilih berdasarkan kriteria inklusi yaitu pasien berusia $\geq 18$ tahun yang terdiagnosis dengan keganasan yang menyebabkan ikterus obstruktif melalui ERCP, dan telah menjalani EUS atau MRCP dengan interval maksimum 3 bulan dengan ERCP. Kriteria eksklusi meliputi pasien yang telah terbukti memiliki keganasan sistem bilier sebelumnya, atau pasien dengan ikterus parenkimal selain obstruktif. Analisis statistik dilakukan dengan menggunakan IBM SPSS Statistics 20.

Hasil: Didapatkan 54 subyek dengan usia rata-rata 56,48 $\pm 11,37$ tahun. Subyek terdiri dari 29 (53,7\%) laki-laki dan 25 (46,3\%) perempuan. Periode median antara EUS hingga ERCP adalah 0-33 hari, sedangkan MRCP ke ERCP adalah 1-53 hari. Sensitivitas, spesifisitas, nilai prediksi positif, dan nilai prediksi negatif untuk mendiagnosis ikterus obstruktif akibat keganasan adalah 96\%, 60\%, 96\%, dan 60\% pada EUS, dan 90\%, 40\%, 94\%, dan 29\% pada MRCP.

Simpulan: EUS lebih unggul dari MRCP dalam mendiagnosis keganasan yang menyebabkan ikterus obstruktif.

Kata kunci: endoscopic ultrasonography (EUS), ikterus obstruktif, keganasan, magnetic resonance cholangiopancreatography (MRCP)

\section{INTRODUCTION}

Obstructive jaundice is an obstruction of the biliary tract causing bilirubin accumulation within blood and bilirubin deposition within the skin. ${ }^{1}$ The common etiologies of obstructive jaundice were biliary stone and biliary neoplasms. In the USA, in 2017, 1 million new biliary stone cases were diagnosed every year, and the incidence of biliary obstruction was 1 case per $100,000 .^{2,3}$ In the UK, there were 2.8 cases per 100,000 females and 2 cases per 100,000 males. ${ }^{2,3}$ Data in Indonesia in 2007 reported that among patients who underwent endoscopic retrograde cholangiopancreatography (ERCP), the prevalence of biliary stone was the highest (54\%), followed by the tumor of ampulla of vater (17\%), the tumor of the head of the pancreas (13\%), biliary tract stricture (5\%), cholangiocarcinoma (2\%), Klatskin tumor $(2 \%)$, and other etiologies $(7 \%){ }^{4}$

Abdominal ultrasonography as the initial diagnostic modality is more convenient and cost-effective compared with other modalities. ${ }^{5}$ The gold standard for diagnosing obstructive jaundice is ERCP with sensitivity and specificity of $>95 \%$ and $100 \%$ to diagnose biliary tract malignancy. ${ }^{6}$ However, ERCP is an invasive procedure associated with several complications such as bleeding, pancreatitis, and perforation. ${ }^{6,7}$ Other available modalities are magnetic resonance cholangiopancreatography (MRCP) and endoscopic ultrasonography (EUS). $\mathrm{MRCP}$ is a non-invasive procedure, while EUS is an invasive procedure that is operator-dependent. ${ }^{6,8} \mathrm{ERCP}$ procedure may be conducted simultaneously at the same time with the EUS allowing earlier diagnosis and management. ${ }^{6,8}$ Makmun et al. stated that the sensitivity ( $97 \%$ vs. $57 \%$ ) and specificity ( $81 \%$ vs. $40 \%$ ) of EUS were better than MRCP to diagnose choledocholithiasis in Indonesia. ${ }^{8}$ However, consensus on sensitivity and specificity of EUS compared with MRCP to diagnose biliary tract malignancy has not been declared. Based on a meta-analysis by Garrow et al which analyzed 36 studies involving 3,532 patients, the sensitivity and specificity of EUS to diagnose choledocholithiasis were higher (sensitivity $89 \%$, specificity $94 \%$ ) than for the diagnosis of malignancy (sensitivity $78 \%$, specificity $84 \%) .{ }^{9}$ However, Garrow et al's study did not address 
a comparison between EUS and MRCP to diagnose obstructive jaundice caused by malignancy. ${ }^{9}$ Until now, in Indonesia, studies about sensitivity and specificity of EUS compared with MRCP to diagnose biliary tract malignancy and pancreas have not been published. Therefore, we conducted this study to evaluate the sensitivity and specificity of EUS compared with MRCP in patients with obstructive jaundice due to malignancy.

\section{METHOD}

This study was a cross-sectional analytic observational study. The study calculated the sensitivity and specificity of EUS and MRCP in obstructive jaundice due to malignancy compared with the gold standard (histopathological examination from ERCP). We conducted the study in the Medical Record Unit, Gastroenterology Division, Dr. Cipto Mangunkusumo National General Hospital, on January - March 2019 by using a consecutive sampling method. Diagnostic data were collected from the medical record within five years.

Inclusion criteria included males and females aged $\geq 18$ years with a diagnosis of obstructive jaundice due to malignancy (not biliary stone) based on history taking, physical examination, and supporting tests in the period of $2014-2018$, patients with MRCP or EUS data at the initial diagnosis before undergoing ERCP and biopsy, patients with confirmed malignancy based on ERCP or ERCP with biopsies, and a period of maximum three months between MRCP or EUS to ERCP. Exclusion criteria included patients with confirmed primary malignancy with suspicion of metastasis to the biliary tract or biliary system, evidence of parenchymal jaundice occurring concurrently with obstructive jaundice, and previous evidence of biliary tract malignancy.

There were 54 subjects included in this study. Secondary data was collected in Medical Record Unit dr. Cipto Mangunksumo National General Hospital. The first patients who satisfy the criteria were included as subjects of this study using a consecutive sampling method. The secondary data included the EUS or MRCP results, ERCP with the histopathological examination findings, and confounding factors.

Statistical analysis was performed using IBM SPSS Statistics 20. Sensitivity, specificity, positive predictive value, negative predictive value, and likelihood ratio will be described. Ethical clearance was licensed by the Ethical Committee of the Faculty of Medicine Universitas Indonesia.

\section{RESULTS}

There were 54 subjects analyzed within this study. Subjects consisted of 29 (53.7\%) males and 25 (46.3\%) females with mean age of $56.48 \pm 11.37$ years. The median period between EUS and ERCP was $0(0-$ 33) days, while the median period between MRCP and ERCP was 11 (1-53) days. The characteristics of subjects were demonstrated in Table 1.

Table 1. Demographic characteristic of the subjects

\begin{tabular}{|c|c|}
\hline Patients characteristics & $n=54$ \\
\hline \multicolumn{2}{|l|}{ Gender, n (\%) } \\
\hline Male & $29(53.7)$ \\
\hline Female & $25(46.3)$ \\
\hline Mean Age \pm SD (years) & $56.48 \pm 11.37$ \\
\hline \multicolumn{2}{|l|}{ Ethnic, $n(\%)$} \\
\hline Acehnese & $1(1.9)$ \\
\hline Bataknese & $4(7.4)$ \\
\hline Betawinese & $3(5.6)$ \\
\hline Jambinese & $2(3.7)$ \\
\hline Javanese & $27(50)$ \\
\hline Lampungnese & $1(1.9)$ \\
\hline Makassarnese & $1(1.9)$ \\
\hline Manadonese & $1(1.9)$ \\
\hline Padangnese & $3(5.6)$ \\
\hline Palembangnese & $1(1.9)$ \\
\hline Sundanese & $6(11.1)$ \\
\hline Tionghoa & $4(7.4)$ \\
\hline \multicolumn{2}{|l|}{ Education, n (\%) } \\
\hline Elementary/junior high school & $12(22.3)$ \\
\hline Senior/ vocational high school & $19(35.2)$ \\
\hline Bachelor & $23(42.5)$ \\
\hline \multicolumn{2}{|l|}{ Occupation, n (\%) } \\
\hline Unemployed/housewife & $32(59.3)$ \\
\hline Entrepreneur & $7(13.0)$ \\
\hline Private employee & $12(22.2)$ \\
\hline Government employee & $3(5.5)$ \\
\hline \multicolumn{2}{|l|}{ Family history of malignancy, n (\%) } \\
\hline Positive & $14(25.9)$ \\
\hline Negative & $40(74.1)$ \\
\hline \multicolumn{2}{|l|}{ Smoking history, n (\%) } \\
\hline Positive & $22(40.7)$ \\
\hline Negative & $32(59.3)$ \\
\hline \multicolumn{2}{|l|}{ Alcohol consumption, n (\%) } \\
\hline Positive & $7(13.0)$ \\
\hline Negative & $47(87.0)$ \\
\hline VAS of initial abdominal pain & $3(0-7)$ \\
\hline \multicolumn{2}{|l|}{ Nausea/vomiting, n (\%) } \\
\hline Positive & $44(81.5)$ \\
\hline Negative & $10(18.5)$ \\
\hline \multicolumn{2}{|l|}{ Body mass index $\left(\mathrm{kg} / \mathrm{m}^{2}\right), \mathrm{n}(\%)$} \\
\hline Underweight & $15(27.7)$ \\
\hline Normoweight & $34(63.0)$ \\
\hline Overweight & $5(9.3)$ \\
\hline $\begin{array}{l}\text { Median decrease of body weight within the } \\
\text { past three months }(\mathrm{kg}) \text { (range) }\end{array}$ & $5(0-15)$ \\
\hline \multicolumn{2}{|l|}{ Bilirubin level (mg/dL) } \\
\hline Total & $11.25(1.8-39.2)$ \\
\hline Direct & $9.35(1.4-30.8)$ \\
\hline \multicolumn{2}{|l|}{ Hepatitis B infection, n (\%) } \\
\hline Positive & $3(5.6)$ \\
\hline Negative & $51(94.4)$ \\
\hline \multicolumn{2}{|l|}{ Hepatitis C infection, n (\%) } \\
\hline Positive & $2(3.7)$ \\
\hline Negative & $52(96.3)$ \\
\hline \multicolumn{2}{|l|}{ Diabetes mellitus, n (\%) } \\
\hline Positive & $10(18.5)$ \\
\hline Negative & $44(81.5)$ \\
\hline \multicolumn{2}{|l|}{ Median Period until ERCP (days) (range) } \\
\hline \multicolumn{2}{|l|}{ Endoscopic ultrasound (EUS) } \\
\hline Magnetic resonance & $0(0-33)$ \\
\hline cholangiopancreatography (MRCP) & $11(1-53)$ \\
\hline
\end{tabular}


All subjects underwent EUS and MRCP examination. Among 54 subjects who underwent EUS, 49 (90.7\%) subjects were diagnosed with pancreaticobiliary malignancy. On MRCP, there were 47 (87\%) subjects with malignancy. Based on ERCP examination (gold standard), there were 49 subjects (98\%) diagnosed with malignancy, and 48 of them were in the advanced stage (unresectable).

Based on ERCP examination, the type of malignancy commonly found was a tumor of the head of the pancreas (50\%). Similar findings were also observed in EUS and MRCP examination. The findings of specific malignancies (tumor of ampulla of vater, the tumor of the head of the pancreas, cholangiocarcinoma, other malignancies, and non-malignancy) for each modality were shown in Table 2.

Table 2. Endoscopic ultrasound (EUS) $(n=54)$, magnetic resonance cholangiopancreatography (MRCP) $(n=54)$, and endoscopic retrograde cholangiopancreatography (ERCP) (n = 54) findings among patients with obstructive jaundice

\begin{tabular}{llll}
\hline Findings & $\begin{array}{l}\text { EUS } \\
\mathbf{n}(\%)\end{array}$ & $\begin{array}{l}\text { MRCP } \\
\mathbf{n}(\%)\end{array}$ & $\begin{array}{l}\text { ERCP } \\
\mathbf{n}(\%)\end{array}$ \\
\hline Tumor of ampulla of vater & $12(22.2)$ & $8(14.8)$ & $6(11.1)$ \\
Tumor of head of pancreas & $21(38.9)$ & $24(44.4)$ & $27(50.0)$ \\
Cholangiocarcinoma & $12(22.2)$ & $7(13.0)$ & $12(22.2)$ \\
Other malignancies & $4(7.4)$ & $8(14.8)$ & $4(7.4)$ \\
Non- malignancy & $5(9.3)$ & $7(13.0)$ & $5(9.3)$ \\
\hline
\end{tabular}

Each of the EUS and MRCP findings was compared with ERCP (gold standard) to confirm the specificity of EUS and MRCP for diagnosis of malignancy. For EUS examination, there were $43 / 49$ (87.7\%) subjects with malignancy diagnosis, which were confirmed by ERCP. However, for MRCP, there were only 39/49 (79.6\%) subjects with malignancy diagnosis from which the type of malignancy was verified by ERCP. The proportion of the type of malignancy was shown in detail in Table 3.

Table 3. Types of pancreaticobiliary malignancy diagnosed with endoscopic ultrasound (EUS) $(n=43)$ and magnetic resonance cholangiopancreatography (MRCP) $(n=39)$ after confirmation with endoscopic retrograde cholangiopancreatography (ERCP)

\begin{tabular}{lll}
\hline Type of malignancies & $\begin{array}{l}\text { EUS, } \\
\mathbf{n}(\%)\end{array}$ & $\begin{array}{l}\text { MRCP, } \\
\mathbf{n}(\%)\end{array}$ \\
\hline ERCP & & \\
$\quad$ Tumor of ampulla of vater & $6(14.0)$ & $5(12.8)$ \\
$\quad$ Tumor of the pancreatic head & $21(48.8)$ & $23(59.0)$ \\
Cholangiocarcinoma & $12(27.9)$ & $7(17.9)$ \\
Other malignancies & $4(9.3)$ & $4(10.3)$ \\
\hline
\end{tabular}

Based on histopathology examination, there were 26/54 (48\%) subjects with adenocarcinoma, 14/54 (26\%) with atypical or inconclusive results, and 14/54 (26\%) with negative results.

EUS had higher sensitivity, specificity, positive predictive value, negative predictive value, and positive likelihood ratio than MRCP to diagnose obstructive jaundice due to malignancy. The negative likelihood ratio of EUS was lower than MRCP. The diagnostic value for each modality was shown in Table 4 and Table 5.

Table 4. Endoscopic ultrasound (EUS) and magnetic resonance cholangiopancreatography (MRCP) results compared with endoscopic retrograde cholangiopancreatography (ERCP) results on obstructive jaundice cases due to

\begin{tabular}{lllll}
\hline \multirow{2}{*}{ Diagnostic Method } & \multicolumn{2}{c}{ ERCP (gold standard) } & Total \\
\cline { 3 - 4 } & Malignancy & $\begin{array}{c}\text { Non- } \\
\text { malignancy }\end{array}$ & \\
\hline EUS & Malignancy & 47 & 2 & 49 \\
& Non malignancy & 2 & 3 & 5 \\
MRCP & Malignancy & 44 & 3 & 47 \\
& Non malignancy & 5 & 2 & 7 \\
\hline
\end{tabular}

The sensitivity, specificity, positive predictive value, and negative predictive value to diagnose obstructive jaundice due to malignancy were $96 \%$, $60 \%, 96 \%, 60 \%$ in EUS, and $90 \%, 40 \%, 94 \%, 29 \%$ in MRCP, respectively. The positive likelihood ratio and negative likelihood ratio were 2.40 and 0.07 in EUS, while in MRCP were 0.07 and 0.26 , respectively.

Receiver operating characteristic (ROC) analysis was also performed. Area under the curve (AUC) for EUS was 78\% (95\% CI: 51-100\%; $\mathrm{p}=0.041)$ while AUC for MRCP was 64.9\% (95\% CI: 36.2-93.6\%; $p=0.276$ ).

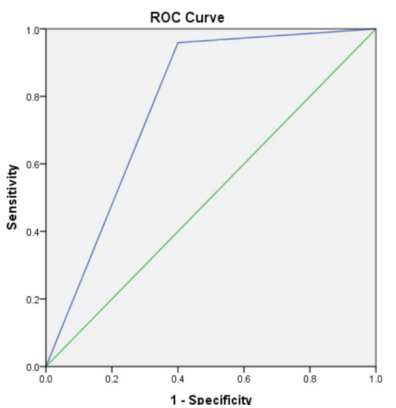

Figure 1. AUC for EUS (a) and MRCP (b)

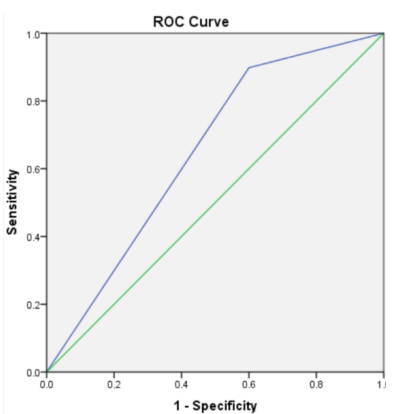

\section{DISCUSSION}

Most of the patients in this study were male $(53.7 \%)$, with a mean age of $56.48 \pm 11.37$ years. This result was coherent with the study by Mohamadnejad et al in which male patients were more prevalent than female patients. ${ }^{10}$ Goyani et al. also reported that most of the patients in the study were in the age range from $51-60$ years (23.3\%). ${ }^{11}$ Besides, a study in Indonesia by Makmun et al also reported similar demographic characteristics among patients with obstructive jaundice. The ratio between male and female patients was $3: 2$, with a mean age of $52.9 \pm 13.31$ years. $^{8}$

In this study, abdominal pain was reported in $87.04 \%$ of patients, and nausea/vomiting in $81.5 \%$. A similar finding was also reported by Goyani et al. in which abdominal pain was the second most common symptom $(86.6 \%){ }^{11}$ 
There were 40/54 (74.1\%) subjects without a family history of malignancy. This result was coherent with the pooled result of 12 retrospective studies (2,246 cases) by Dyke et al, which reported no association between family history and risk of biliary tract malignancy. ${ }^{12}$

The median of total and direct bilirubin of subjects in this study were $11.25(1.8-39.2) \mathrm{mg} / \mathrm{dL}$ and 9.35 (1.4-30.8) $\mathrm{mg} / \mathrm{dL}$, respectively. This value was higher than the study by Palmucci et al in Italy, in which the mean of total bilirubin was $6.85 \mathrm{mg} / \mathrm{dL}$, and direct bilirubin was $4.12 \mathrm{mg} / \mathrm{dL}$. The difference could be caused by the difference of characteristics of patients in Italy and Indonesia; and the lower total subjects (45 subjects) in those studies. ${ }^{13}$

Based on logistic regression analysis, Jin et al. reported that bilirubin level, particularly direct bilirubin, was one of the primary predictors for malignancy of the head of the pancreas $(p<0,001)$ besides age and abdominal pain. ${ }^{14} \mathrm{Garcea}$ et al reported that a bilirubin level of $100 \mu \mathrm{mol} / \mathrm{L}$ had a sensitivity of $71.9 \%$, a specificity of $86.9 \%$, and a positive predictive value of $5.5 \%$ to diagnose malignancy. Specificity is increased at higher bilirubin level. ${ }^{15}$

This study showed that EUS was superior to diagnose malignancy causing obstructive jaundice than MRCP with better sensitivity, specificity, positive predictive value, and negative predictive value.

The specificity of both diagnostic modalities of EUS and MRCP were lower than the sensitivity of both modalities. These results could be caused by the high number of true negative and false positive for both diagnostic modalities depending on operator ability. A study by Schembre et al, Cho et al, and Lennon AM et al. reported that operator ability and the specificities of both diagnostic modalities could influence the effectiveness of EUS. ${ }^{16-18}$ ASGE also recommended that endoscopic operator underwent 190 supervised EUS procedure (including 75 cases of pancreaticobiliary and 75 mucosal cancer staging). ${ }^{19}$

In this study, the specificity of EUS was better because the capacity of EUS to diagnose lymph node metastasis due to malignancy was better than MRCP. A meta-analysis by Garrow et al which consisted of 36 studies involving 3,532 patients, reported that the sensitivity and specificity of EUS to diagnose malignancy were $78 \%$ and $84 \% .{ }^{9}$ Singh et al also reported coherent results in which the specificity of EUS was better compared with MRCP (95\% vs. $89 \%) .{ }^{20}$ The study by Canto et al reported a similar result with this study, in which EUS was better than MRCP to diagnose pancreatic neoplasms $(42.6 \%$ vs. $33.3 \%){ }^{21}$ Jiwani et al reported that MRCP had a sensitivity of $95,35 \%$, a specificity of $94,74 \%$, a positive predictive value of $93,18 \%$, and a negative predictive value of $94,43 \%$. The difference between the study by Jiwani et al and our current study could be caused by the difference in the gold standard modality. Jiwani et al. also used histopathology examination from surgical specimens, while our present study only used ERCP as the gold standard. ${ }^{22}$

The diagnostic value of EUS and MRCP for obstructive jaundice due to malignancy was different with choledocholithiasis. Based on Makmun D et al, the sensitivity of MRCP ( $90 \%$ vs. $81 \%)$ was better for diagnosis of malignancy than choledocholithiasis. Besides, the positive predictive value of EUS: (96\% vs. $87 \%$ ) and MRCP (94\% vs. $68 \%)$; and negative predictive value of EUS: ( $60 \%$ vs. $88 \%)$ and MRCP ( $29 \%$ vs. $74 \%)$ was better in malignancy compared with choledocholithiasis. ${ }^{8}$ The sensitivity and positive predictive value of both modalities were not significantly different from Materne et al. However, specificity (EUS: 88\%; MRCP: 94\%) and negative predictive value (EUS: 94\%; MRCP: $84 \%$ ) between the two studies were far higher. ${ }^{24}$ These results show that the ability of the operator was important for diagnostic accuracy with both modalities. Besides, the specification of modalities used in this study was similar to the study by Makmun D et al and Materne et al which used EUS with radial probe and frequency of $7.5 \mathrm{MHz}$ and MRCP 1.5 Tesla. ${ }^{8,24}$

This study showed that the most common etiology of obstructive jaundice was pancreatic head cancer $(55.1 \%)$. The result was similar to the study by Jiwani et al. in which the most common malignancy discovered was pancreatic head cancer (26.79\%). ${ }^{22}$ However, other studies by Goyani et al and Suthar et al found that the most common type of cancer was cholangiocarcinoma, with a proportion of $20 \%$ and $62 \%$, respectively. ${ }^{11,25}$ Singh et al reported that periampullary carcinoma was the most common malignancy pathology causing obstructive jaundice. ${ }^{26}$ This discrepancy might be caused by the different number of subjects enrolled in both of those studies. Another study by Makmun et al from Indonesia discovered that cancer of the head of the pancreas was the most common type of cancer (54.2\%) found in patients undergoing EUS$\mathrm{BD}$, followed by the periampullary tumor $(41.6 \%)$ and cholangiocarcinoma $(4.2 \%) .{ }^{27}$

A meta-analysis by Maisonneuve et al reported that a history of smoking, diabetes mellitus, and a family history of malignancy were moderate risk 
factors for pancreatic cancer $(\mathrm{RR}=1.5-1.9) .{ }^{28}$ This was different from our study results, which showed that $59.3 \%$ of patients were non-smokers, $81.5 \%$ did not have a history of diabetes mellitus, and $74.1 \%$ did not have a family history of pancreaticobiliary cancer. This difference might be caused by the different demographics and characteristics of our patients.

EUS was generally more accurate in diagnosing specific types of malignancy compared with MRCP. The accuracy of EUS compared with ERCP in diagnosing cholangiocarcinoma was $100 \%$. However, MRCP only detected 7/12 (58.3\%) cases of cholangiocarcinoma. Concerning cholangiocarcinoma, a study by Mohamadnejad et al. found that the accuracy of EUS in the diagnosis of cholangiocarcinoma was $94 \%$, much higher than the accuracy of MRCP, which was only $42 \% .{ }^{10}$ Another study by Eloubeidi et al found that the sensitivity and specificity of EUS were $86 \%$ and $100 \%$, respectively, with an accuracy of $88 \% .{ }^{29} \mathrm{~A}$ study by Zidi et al. showed that the accuracy of MRCP in the diagnosis of hilar cholangiocarcinoma was $78 \% .{ }^{30}$ Our study did not specify the type of cholangiocarcinoma (intraductal, hilar, or extra ductal) and thus could affect the accuracy of EUS in our research.

A study by Artifon et al. reported that EUS was more sensitive and specific than a CT scan in the staging of the tumor $(\mathrm{T})$ and node $(\mathrm{N})$. The accuracy of tumor staging by EUS was in the range of $62-90 \%$, with the best sensitivity found in the N0 tumor $(88 \%)$ and the best specificity in the T3 tumor (87\%). ${ }^{31}$ Another study by Domagk et al. reported that the accuracy of MRCP in classifying benign and malignant lesion was only $58 \%$, much less than the accuracy of ERCP, which had an accuracy of $76 \%{ }^{32}$

The accuracy of EUS in the diagnosis of the pancreatic head tumor was less than MRCP (77.7\% vs. $85.2 \%$ ). This result was similar to the study by Hwang et al., which showed that the area under the curve (AUC) of MRCP was higher than EUS $(71.2 \%$ vs. $68.8 \%$ ), respectively. ${ }^{33}$ The diagnostic value of EUS for detecting pancreatic tumors could be improved by including a fine-needle aspiration (FNA) procedure. A meta-analysis by Puli et al., which evaluated 41 studies (4,766 patients), found that the sensitivity and specificity of EUS-FNA to diagnose the etiology of solid pancreatic mass were $86.8 \%$ and $95.8 \%$, respectively, with a positive predictive value of 15.2 and a negative predictive value of $0.17 .{ }^{34}$

The time interval between EUS and MRCP with the ERCP procedure might affect the results of the diagnostic performance of EUS and MRCP in this study. In our study, the median interval between EUS and ERCP was 0 (0-33), much shorter than the median interval between MRCP and ERCP, which was 11 days (1-53 days). Materne et al also showed that a long interval between EUS or MRCP and the final diagnosis might influence the diagnostic accuracy. ${ }^{24}$

\section{Stadium of Cancer}

Our study showed that $98 \%$ of subjects (48/49) presented with a late-stage and unresectable tumor. Most of the patients in this study were referred from various primary and secondary health facilities in Indonesia. The lack of diagnostic modality in primary and secondary health facilities led to late diagnosis and referral. Besides, most of the patients in this study had a low to moderate education level, which was associated with late presentation to healthcare facilities.

EUS and MRCP have an essential role in the staging of biliary malignancies. The 2016 ESMO Guideline stated that EUS was very helpful in $\mathrm{N}$-staging (especially when combined with FNA/ biopsy) and could also obtain information about blood vessel involvement. On the other hand, MRCP was useful for T-staging and the detection of biliary duct involvement. ${ }^{35}$

A study by Artifon et al showed that EUS was more sensitive and specific than a CT scan for the staging of the tumor $(\mathrm{T})$ and node $(\mathrm{N})$. The sensitivity of EUS for T-staging (75-85\%) was comparable with the sensitivity for N-staging (70-88\%). However, the specificity of T-staging (70-88\%) was higher than the specificity for N-staging (64-87\%). ${ }^{31}$ Shoup et al stated that the accuracy of EUS in diagnosing tumor was superior to CT scan in both tumor size of $<2 \mathrm{~cm}$ and $\geq 2$ cm (90\% vs. $70 \%$ and $100 \%$ vs. $87.5 \%$, respectively). ${ }^{36}$

A meta-analysis by Nawaz et al from 29 studies (1,330 patients) showed that the sensitivity and specificity of EUS for N-staging were $69 \%$ and $81 \%$, respectively. ${ }^{37}$ Another meta-analysis by $\mathrm{Li}$ et al, showed similar results, in which EUS had a sensitivity of $62 \%$, a specificity of $74 \%$, and an AUC of 0.79 for $\mathrm{N}$-staging. However, the accuracy increased to $88 \%$ when it was combined with FNA/biopsy. ${ }^{38}$ Therefore, EUS and MRCP could be the alternative modalities for staging biliary malignancy.

Several considerations determine the diagnostic modality for obstructive jaundice, including safety, accuracy, time, and cost-effectiveness of each diagnostic modality. A review from Gornals et al stated that EUS was relatively safer and more comfortable for patients. Besides, EUS was more accurate in detecting 
small tumors or lesions (especially pancreatic tumors), which allowed locoregional staging of the neoplastic lesion. ${ }^{37-39}$ EUS was also a time-saving and costeffective procedure since tissue can also be obtained during EUS (by FNA or biopsy). EUS could also reduce the requirement for sedation. ${ }^{39,40}$ However, EUS is still an invasive procedure that depended highly on the operator's skills and the devices' quality. ${ }^{16,38}$

MRCP could give a better visualization and 3D projection of the biliary tracts without contrast injection, which reduces the risk of cholangitis. MRCP could also accurately determine the obstruction and tumor extension level, including blood vessel involvement in all types of biliary malignancies. . $^{41,42}$ However, MRCP requires a relatively long time to complete, expensive, and can not be done at the same time with ERCP.

Both EUS and MRCP have difficulty detecting distant metastasis and distal lesion (such as in cholangiocarcinoma). Proximal lesions are more difficult to reach because the proximal perihilar biliary duct's location is far from the duodenal and stomach lumen. ${ }^{10}$

Potential limitations of this study stemmed from the fact that EUS interpretation was very dependent on the operator's skills, which could result in false negative results. However, even with that potential bias, the result of this study did show that EUS had higher diagnostic accuracy than MRCP. Besides, in this study, EUS was performed by expert gastroenterologists with extensive experience. Most patients in this study also had advanced stage cancers. Further studies might be needed to determine the accuracy of EUS and MRCP in detecting early-stage cancer. The advantage of our study is that it is the first study comparing EUS and MRCP for the diagnosis of malignant obstructive jaundice in Indonesia. EUS is still a relatively new modality in Indonesia, and our study showed that it has a high diagnostic accuracy for the patient population.

\section{CONCLUSION}

EUS was more superior to MRCP in the diagnosis of biliary malignancy causing obstructive jaundice. The sensitivity, specificity, positive predictive value, and negative predictive value of EUS were better than MRCP.

\section{REFERENCES}

1. Hall, John Edward, and Guyton, Arthur C. Textbook of Medical Physiology, Saunders/Elsevier 2001.p.841.
2. Wilkins T, Agabin E, Varghese J, Talukder A. Gallbladder Dysfunction: Cholecystitis, Choledocholithiasis, Cholangitis, and Biliary Dyskinesia. Prim Care 2017;44:575-97.

3. American Cancer Society. Cancer Facts \& Figures 2018: Bile Duct Cancer. Atlanta: American Cancer Society 2018.

4. Makmun D, Sajuthi D, Daldiyono D, Winarto A, Sulistiawati E. Effect of intravenous polyunsaturated fatty acids administration on gastric mucosal integrity in pig-tailed macaques with obstructive jaundice. Indones J Gastroenterol Hepatol Dig Endosc 2011;12:8-14.

5. Prachayakul V, Aswakul P, Bhunthumkomol P, Deesomsak M. Diagnostic yield of endoscopic ultrasonography in patients with intermediate or high likelihood of choledocholithiasis: a retrospective study from one university-based endoscopy center. BMC Gastroenterol 2014;14:165.

6. Kaltenthaler EC, Walters SJ, Chilcott J, Blakeborough A, Vergel YB, Thomas S. MRCP compared to diagnostic ERCP for diagnosis when biliary obstruction is suspected: a systematic review. BMC Med Imaging 2006;6:9.

7. ASGE Standards of Practice Committee, Anderson MA, Fisher L, et al. Complications of ERCP. Gastrointest Endosc 2012;75:467-73.

8. Makmun D, Fauzi A, Shatri H. Sensitivity and specificity of magnetic resonance cholangiopancreatography versus endoscopic ultrasonography against endoscopic retrograde cholangiopancreatography in diagnosing choledocholithiasis: The Indonesian Experience. Clin Endosc 2017;50:486-90.

9. Garrow D, Miller S, Sinha D, Conway J, HofFman BJ, Hawes RB, et al. Endoscopic ultrasound: a meta-analysis of test performance in suspected biliary obstruction. Clin Gastroenterol Hepatol 2007;5:61.

10. Mohamadnejad M, DeWitt JM, Sherman S, LeBlank JK, Pitt $\mathrm{HA}$, House MG, et al. Role of EUS for preoperative evaluation of cholangiocarcinoma: a large single-center experience. Gastrointest Endosc 2011;73:71-8.

11. Goyani B, Ukani B, Patel M, Shah B, Vadel M. Ultrasonography and magnetic resonance cholangiopancreatography correlation in patients with obstructive jaundice. Int J Med Sci Public Health 2015;4:1010-14.

12. Dyke ALV, Langhamer MS, Zhu B, Pfeiffer RM, Albanes D, Andreotti G. Family history of cancer and risk of biliary tract cancers: results from the biliary tract cancers pooling project. Cancer Epidemiol Biomarkers Prev 2018;27:348-51.

13. Palmucci S, Mauro LA, La Scola S, Incarbone $\mathrm{S}$, Bonanno $\mathrm{G}$, Milone $\mathrm{P}$, et al. Magnetic resonance cholangiopancreatography and contrast-enhanced magnetic resonance cholangiopancreatography versus endoscopic ultrasonography in the diagnosis of extrahepatic biliary pathology. Radiol Med 2010;115:732-46.

14. Jin $\mathrm{X}, \mathrm{Wu} \mathrm{Y}$. Diagnostic utility of clinical and biochemical parameters in pancreatic head malignancy patients with normal carbohydrate antigen 19-9 levels. Afr Health Sci 2015;15:123-30.

15. Garcea G, Ngu W, Neal CP, Dennison AR, Berry DP. Bilirubin levels predict malignancy in patients with obstructive jaundice. HPB (Oxford). 2011;13:426-30.

16. Schembre D, Lin O. Frequency and costs of echo endoscope repairs: results of a survey of endosonographers. Endoscopy 2004;36:982-6.

17. Cho CM. Training in endoscopy: endoscopic ultrasound. Clin Endosc 2017;50:340-44.

18. Lennon AM, Penman ID. Endoscopic ultrasound in cancer staging. British Medical Bulletin 2007;84:81-98. 
19. Eisen GM, Dominitz JA, Faigel DO, Goldstein JA, Petersen BT, Raddawi HM, et al. Guidelines for credentialing and granting privileges for endoscopic ultrasound. Gastrointest Endosc 2001;54:811-4.

20. Singh A, Gelrud A, Agarwal B. Biliary strictures: diagnostic considerations and approach. Gastroenterol Rep (Oxf) 2015;3:22-31.

21. Canto MI, Hruban RH, Fishman EK, Kamel IR, Schulick R, Zhang Z, et al. American Cancer of the Pancreas Screening (CAPS) Consortium. Frequent detection of pancreatic lesions in asymptomatic high-risk individuals. Gastroenterology 2012;142:796-804.

22. Jiwani MS, Banode PJ, Kharche AD, Jiwani AA, Vaidhya SV. Role of magnetic resonance cholangiopancreatography in cases of obstructive jaundice in correlation with ultrasonography. International Journal of Recent Surgical and Medical Sciences 2016;2:70-84.

23. Sugita R. Magnetic resonance evaluations of biliary malignancy and condition at high-risk for biliary malignancy: current status. World J Hepatol 2013;5:654-65.

24. Materne R, Van Beers BE, Gigot JF, Jamart J, Geubel A, Pringot J, et al. Extrahepatic biliary obstruction: magnetic resonance imaging compared with endoscopic ultrasonography. Endoscopy 2000;32:3-9.

25. Suthar M, Purohit S, Bhargav V, and Goyal P. Role of MRCP in differentiation of benign and malignant causes of biliary obstruction. J Clin Diagn Res 2015;9:TC08-TC12.

26. Singh A, Mann HS, Thukral CL, Singh NR. Diagnostic accuracy of MRCP as compared to ultrasound/CT in patients with obstructive jaundice. J Clin Diagn Res 2014;8;103-7.

27. Makmun D, Fauzi A, Abdullah M, Syam AF. The role of EUS-BD in the management of malignant obstruction: the Indonesian perspective. Diagnostic and Therapeutic Endoscopy 2017;1:1.

28. Maisonneuve P, Lowenfels AB. Risk factors for pancreatic cancer: a summary review of meta-analytical studies. International Journals of Epidemiology 2015;186-98.

29. Eloubeidi MA, Chen VK, Jhala NC, Eltoum IE, Jhala D, Chhieng DC, et al. Endoscopic ultrasound-guided fine needle aspiration biopsy of suspected cholangiocarcinoma. Clin Gastroenterol Hepatol2004;2:209-13.

30. Zidi SH, Prat F, Le Guen O, Rondeau Y, Pelletier G. Performance characteristics of magnetic resonance cholangiography in the staging of malignant hilar strictures. Gut 2000;46:103-6.

31. Artifon ELA, Couto D Jr, Sakai P, Silveria EB. Prospective evaluation of EUS versus CT scan for staging of ampullary cancer. Gastrointest Endosc. 2009;70:290-6.

32. Domagk D, Wessling J, Reimer P, Hertel L, Poremba C, Senninger N, et.al. Endoscopic retrograde cholangiopancreatography, intraductal ultrasonography, and magnetic resonance cholangiopancreatography in bile duct strictures: a prospective comparison of imaging diagnostics with histopathological correlation. Am J Gastroenterol 2004;99:1684.

33. Hwang J, Kim YK, Min JH, Jeong WK, Hong SS, Kim H. Comparison between MRI with MR cholangiopancreatography and endoscopic ultrasonography for differentiating malignant from benign mucinous neoplasms of the pancreas. Eur Radiol 2018;28:179-87.

34. Puli SR, Bechtold ML, Buxbaum JL, Eloubeidi MA. How good is endoscopic ultrasound-guided fine-needle-aspiration in diagnosing the correct etiology for a solid pancreatic mass: a meta-analysis and systematic review. Pancreas. 2013;42:20-6.
35. Valle JW, Borbath I, Khan AS, Huguet F, Gruenberger T. Biliary cancer: ESMO Clinical Practice Guidelines for diagnosis, treatment and follow-up. Annals of Oncology 2016;27:28-37.

36. Shoup M, Hodul P, Aranha GV, Choe D, Olson M, Leya J, et al. Defining a role for endoscopic ultrasound in staging periampullary tumors. Am J Surg 2000;179:453-6.

37. Nawaz H, Fan CY, Kloke J, Khalid A, McGrath K, Landsittel $\mathrm{D}$, et al. Performance characteristics of endoscopic ultrasound in the staging of pancreatic cancer: a meta-analysis. JOP 2013;14:484-97.

38. Li JH, He R, Li YM, Cao G, Ma QY, Yang WB. Endoscopic ultrasonography for tumor node staging and vascular invasion in pancreatic cancer: a meta-analysis. Dig Surg 2014;31:297305.

39. Gornals JB, Esteban JM, Guarner-Argente C, Marra-Lopez C, Repiso A, Sendino O, et al. Endoscopic ultrasound and endoscopic retrograde cholangiopancreatography: Can they be successfully combined? Gastroenterol Hepatol 2016;39:62742.

40. Strongin A, Singh H, Eloubeidi MA, Siddiqui AA. Role of endoscopic ultrasonography in the evaluation of extrahepatic cholangiocarcinoma. Endoscopic Ultrasound 2013;2:71-6.

41. Săftoiu A, Vilmann P. Differential diagnosis of focal pancreatic masses by semiquantitative EUS elastography: between strain ratios and strain histograms. Gastrointest Endosc 2013;78:188-9.

42. Weber A, Schmid RM, Prinz C. Diagnostic approaches for cholangiocarcinoma. World J Gastroenterol 2008;14:4131-36. 